\title{
The Varying Challenge of Islamophobia for the EU: On Anti-Muslim Resentments and Its Dividend for Right-Wing Populists and Eurosceptics-Central and Eastern Europe in a Comparative Perspective
}

\section{Gert Pickel and Cemal Öztürk}

G. Pickel $(\bowtie)$

Leipzig University, Leipzig, Germany

e-mail: pickel@rz.uni-leipzig.de

C. Öztürk

University Duisburg-Essen, Duisburg, Germany

e-mail: cemal.oeztuerk@leuphana.de

(C) The Author(s) 2021

A. Lorenz and L. H. Anders (eds.), Illiberal Trends and Anti-EU Politics in East Central Europe, Palgrave Studies in European Union Politics, https://doi.org/10.1007/978-3-030-54674-8_3 


\section{Introduction: Is There a Connection BetWEen IsLamophobia, Right-Wing POPULISM AND EUROSCEPTICISM? ${ }^{1}$}

In the 2019 European elections, right-wing populist and far-right parties ${ }^{2}$ witnessed a clear plus in votes. While their electoral success has fallen short of the nightmare scenarios of the supporters of the European Union, ${ }^{3}$ it is an enormous challenge for the EU. Whether in government or as opposition in national parliaments, right-wing populists have successfully torpedoed joint action of the $\mathrm{EU}$ in recent years. A prominent example is the resistance of the Visegrád States against binding quotas for the distribution of refugees and asylum seekers. Their political agenda threatens the much-vaunted 'European Community' and its values in the name of national interests. This unexpected comeback of nationalism weakens the EU beyond Eastern Europe, as something like Brexit shows. It is another write-in likely to give European right-wing populists a further boost.

The so-called refugee crisis is frequently mentioned as a catalysing factor. The demand for a restrictive immigration regime has become the battle horse of right-wing populists ever since. The allusions to the so-called refugee crisis, however, are far too simplistic from our point of view. They do not explain how and why the immigration of 2.3 million people-which constitute less than $0.5 \%$ of the total population of the EU-has succeeded in sparking deep conflicts. In addition, the label 'refugee crisis' conceals the fact that the controversy over migration has indeed become an anti-Islam discourse. Based on existing studies, we hypothesise that Islamophobia-understood as a collective hostility vis-à-vis Muslims and their religion-is tied to Eurosceptic positions. Right-wing populists have instrumentalised this connection to increase

\footnotetext{
${ }^{1}$ Substantial parts of the article stem from research activities carried out in the research group 'Multiple Secularities-Beyond the West, Beyond Modernities' at the University of Leipzig, which is funded by the German Research Foundation (DFG). for further information see Www.Multiple.Secularities.de.

${ }^{2}$ In our article, we use the well-known term right-wing populism. In the relevant research literature, however, the radical right-wing orientation of these parties is increasingly emphasised, while the populist style of pitching ideological content is regarded as a supplemental feature (see Mudde 2019).

${ }^{3}$ Empirical findings reveal a high mobilisation of EU supporters (Stark et al. 2019).
} 
citizens' distance from the EU and thus exacerbate an erosion of its support among citizens.

To investigate whether Islamophobia has become a driver for Euroscepticism, we first shed light on the extent of derogatory attitudes towards Muslims. We demonstrate that Islamophobic attitudes among citizens have become a pan-European strain for the EU, while at the same time, they are more pronounced in Eastern Europe. Secondly, using the European Social Survey data, we scrutinise the IslamophobiaEuroscepticism Nexus in a comparative perspective, showing that in Western Europe, it is primarily (though not exclusively) supported by voters of right-wing populist parties, while in the new EU member states, right-wing populists and mainstream politicians attempt to outbid each other when it comes to Islamophobic statements. This strengthens antiEU efforts. Thirdly, we show that the nexus works separately from the presence or absence of Muslims. Finally, we discuss our conclusion that the hostile stance of the Visegrád States against immigrants is therefore in line with public opinion. Supranational bargaining attempts like the quota system for the distribution of refugees are thus doomed to failure. However, the consequences of Islamophobia and Euroscepticism for the EU are controversial.

\section{THEORISING THE ISLAMOPHOBIA-EUROSCEPTICISM NeXUS}

A linkage between anti-migration attitudes and individual stances towards the EU is the subject of various studies investigating the causes of Euroscepticism. It appears that citizens with negative attitudes towards immigrants are more likely to have negative outlooks vis-à-vis the EU (Stockemer et al. 2018; Yavçan 2013). Obviously, the EU is seen as a stakeholder in migration policy issues (e.g. Schengen, Dublin Agreement \& Frontex). Among other reasons, this explains why the so-called refugee crisis has increasingly become a stress factor for Brussels (Stockemer et al. 2018). Eurobarometer (2018) data also reveal that, since 2015, citizens have identified immigration and terrorism as the main problems faced by the EU (see Fig. 1). Revealingly, fear of terror and immigration are mentioned in the very same breath. This pattern suggests that the anti-immigration discourse of recent years has de facto become an anti-Islam discourse, primarily directed against Muslims (Pickel 2018; Stockemer et al. 2019). 


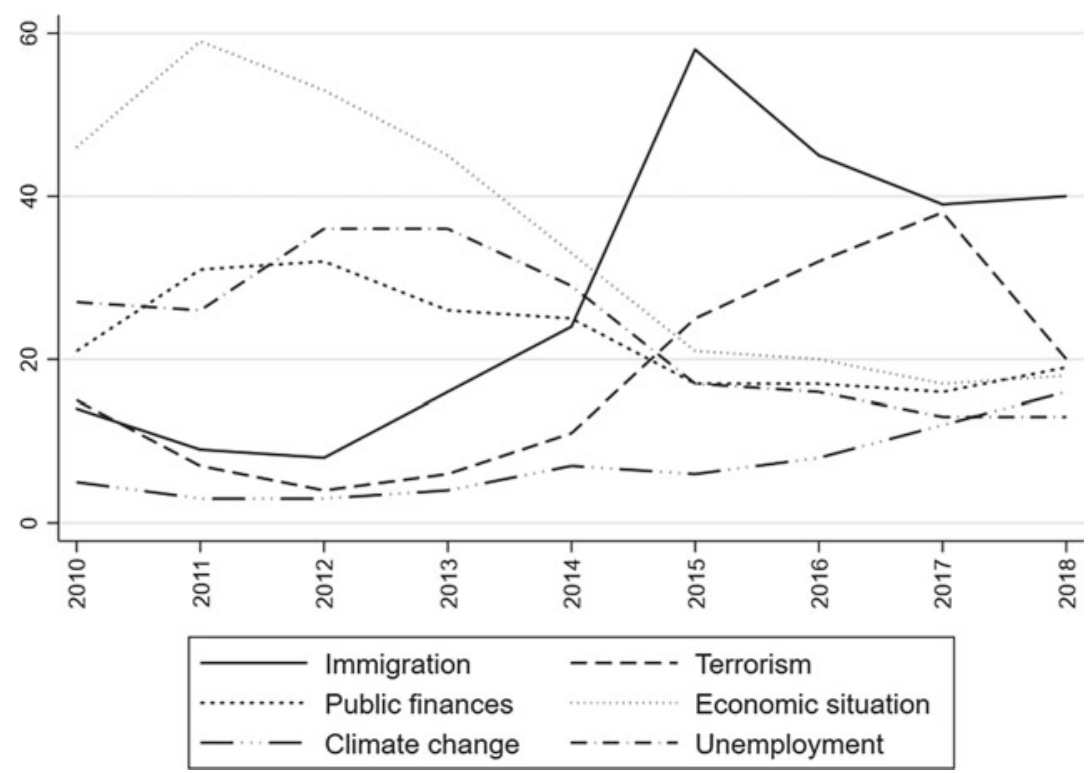

Fig. 1 Key issues faced by the EU from the perspective of citizens (Source Eurobarometer [2018])

We stress, however, that the Islamophobic discourses are not a new trend (Pickel and Öztürk 2018a). The so-called refugee crisis only had a catalysing effect that activated and intensified already existing resentments against Muslims. Two factors were decisive for this: First, most immigrants who have arrived since 2015 are either Muslims or originate from predominantly Muslim societies, such as Syria, Iraq and Afghanistan. Secondly, Muslims have been associated with terrorism since the 9/11 attacks and whole series of ISIS attacks in European cities since 2015 have further amplified such perceptions. In any case, it is hardly deniable that many Europeans perceive Muslims as bigots, dangerous and violence-prone (Pickel and Pickel 2019).

The impact of such threat perceptions on the emergence of collective prejudices takes centre stage in the Integrated Threat Theory (Stephan and Stephan 1996). In essence, this theory assumes that fears and threat perceptions provide the driving force underlying hostile attitudes vis-àvis outgroups. This socio-psychological framework of prejudice research 
is at the end of the day a refined version of the Social Identity Theory (Tajfel 1982). Social Identity Theory argues that the emergence of resentments is preceded by (a) the construction of collective identities, and (b) a categorisation process. The additional argument of Integrated Threat Theory stresses that collective identities unfold their conflict potential if the outgroup is perceived as a threat. A distinction is drawn between realistic threats covering concrete concerns (such as anxiety about economic decline or worries about inland security), and symbolic threats, standing on more diffuse fears (such as a menace to a country's way of life) (Stephan and Stephan 1996). Both perceptions of threats are no rarities when it comes to Muslims: In popular discourses, they are often presented as a burden for 'native' welfare systems, the fifth colonnade of Islamist terrorism, and as a cultural threat to the liberal achievements of Western societies (Ciftci 2012; Pickel and Yendell 2016).

Since these threat perceptions are widespread, extending all the way into the mainstream of European societies (Kallis 2018), and since citizens blame the EU for issues relating to immigration, our hypothesis is:

H1 Islamophobic orientation patterns correlate with and promote Eurosceptic attitudes.

However, attitudes towards immigrants and the EU do not arise in a vacuum. Citizens use 'information shortcuts' to shape their attitudes towards Brussels and Strasbourg (Roodujin and van Kessel 2019). The positions of individually preferred parties towards the EU and its sociopolitical agenda matter (Steenbergen et al. 2007, for another perspective on the citizens-parties linkage see Chapter 7).

We consider the voters of right-wing populist parties to be predestined for a fusion of Islamophobic and Eurosceptic attitudes because, following the approach of Mudde and Kaltwasser (2017), the nucleus of populist parties is the propagation of an antagonistic conflict between the 'ordinary people' and the allegedly 'alienated, corrupt elites' plus the demand that politics should be decisively determined by the 'volonté générale'. Accompanying this by a nativist 'host ideology', right-wing populists portray the people in an ultra-nationalist manner and with exclusionary intentions as ethnically homogeneous (Mudde and Kaltwasser 2017). The hostility of the European right-wing populists is directed against the national political elites, but also against the EU which is perceived as a citizen-distant 
and elite-dominated institution. Moreover, their complex and opaque decision-making processes are difficult to reconcile with the demand for a direct implementation of the alleged 'volonté générale' (Rooduijin and van Kessle 2019; Werts et al. 2013). Right-wing populists campaign on a pan-European level against Islam and Muslims and agitate against the so-called Islamisation of their nations (Hafez 2014; Kallis 2018; Pickel and Yendell 2018). The Brussels-based bureaucrats have been accused of orchestrating the alleged 'invasion of Muslims' (Kalmar 2018; Krastev 2018).

H2 Voters of right-wing populist parties are particularly susceptible to a combination of Islamophobic and Eurosceptic attitudes.

The Islamophobia-Euroscepticism Nexus, however, operates under strongly varying context conditions. Muslim communities have become a visible reality in everyday life in many Western European and Scandinavian societies. In most Eastern European societies, on the other hand, their presence is marginal. They often make up less than $1 \%$ of the population (PEW 2011). The contact hypothesis (Allport 1971) can serve to assess whether these contextual variations pose a moderating effect upon the Islamophobia-Euroscepticism Nexus (Stockemer et al. 2018). This hypothesis suggests that contact with outgroups can contribute to the erosion of resentments. This, however, is not an automatism.

A prejudice-reducing effect is more likely (a) if there is equal status between the involved groups, (b) if common goals are pursued and (c) if the institutions of a society endorse this contact (Allport 1971). If the contact hypothesis is optimistically transferred to the IslamophobiaEuroscepticism Nexus, one could argue that it is precisely the absence of Muslims that intensifies resentment against them. If Islamophobic attitudes do indeed promote scepticism towards the EU, then it could be assumed that the individual linkage of Islamophobia and Euroscepticism is particularly pronounced in societies with few Muslims.

Studies investigating the causes of Eurosceptic attitudes often do not share this optimistic reading of the contact hypothesis. Azrout et al. (2013) point out that the political situation in many European societies (i.e. nationalism, electoral success of right-wing populists, and widespread fear of Islamist terrorism) would not satisfy the conditions set out by 
Allport (1971). On the contrary, contact under these unfavourable conditions could exacerbate tensions between Muslims and the majority population. The premise is then exactly the opposite. This reading assumes that the individual linkage between Islamophobia and Euroscepticism is much stronger in societies with larger Muslim communities.

According to us, the moderating effect of the presence or absence of Muslim communities on the Islamophobia-Euroscepticism Nexus should not be overestimated. First, studies show that there is a gap between the real and perceived proportion of immigrants with many citizens overestimating their share within the population (Gorodzeisky and Semyonov 2019). Therefore, citizens' subjective perception is decisive. If citizens believe that there are too many immigrants and that their existence is threatening, Eurosceptic attitudes are a very likely consequence (Stockemer et al. 2018). Secondly, several studies were able to validate the assumptions of Allport's (1971) contact hypothesis. An anti-Muslim social climate is particularly pronounced in Eastern Europe, where the number of Muslims is comparatively small (Marfouk 2019; Pickel and Öztürk 2018b; Schlueter et al. 2019). This increasingly salient anti-Muslim social climate, further intensified by the so-called refugee crisis, might have led to a loss of reputation for the EU in Eastern Europe (Krastev 2018). Against this backdrop, we assume that the Islamophobia-Euroscepticism Nexus is not a Western European peculiarity.

H3 The smaller the share of Muslims in the total population, the more pronounced an anti-Muslim social climate is (H3a). However, the Islamophobia-Euroscepticism Nexus is not tempered nor intensified by the different share of Muslims (H3b).

\section{Research Design: Data and Method}

We use the seventh wave of the European Social Survey (2014) as the central database for testing our hypotheses. ${ }^{4}$ This survey allows us to investigate the research guiding hypothesis because citizens were asked whether they would like to see an immigration ban for Muslims and whether they believe that the European unification process has gone too

\footnotetext{
${ }^{4}$ For further information see https://www.europeansocialsurvey.org/.
} 
far. We consider the support of a Muslim ban as a proxy for Islamophobic attitudes (Pickel and Öztürk 2018b). To classify the ideological leanings of parties, we refer to the PopuList of Rooduijn et al. (2019). ${ }^{5}$ The percentage of Muslims in the total population is derived from a publication of the Pew Research Centre (2011).

The ESS (2014) provides a representative survey of $18 \mathrm{EU}$ member states, as well as Israel, Switzerland and Norway. Since the so-called refugee crisis has led to the aforementioned conflict over binding quotas for the distribution of asylum seekers within the EU, we have decided to limit the case selection to its member states. Despite this limited number of cases, we believe that the ESS (2014) is a suitable database for testing our hypotheses. These 18 European societies differ substantially in terms of their geographical location, socio-economic conditions, experience with democracy and the share of Muslims. Since we assume a panEuropean Islamophobia-Euroscepticism Nexus despite these different contextual conditions, our research resembles the idea of a most-different system design (Pickel 2016).

The data were gathered between 2014 and 2015. We do not consider the timing of the survey to be a major problem. We acknowledge that the refugee flows and the political conflicts over their distribution in the EU member states reached their peak after the data were gathered. However, debates about an increased terrorist threat by Muslim immigrants arose when the data were collected. It even coincided with the attack on Charlie Hebdo (January 2015) in 11 states (Castanho Silva 2018). As already mentioned, anti-Muslim hostility is not a new trend in Europe (Pickel and Öztürk 2018a). Even before the so-called refugee crisis, effects between Islamophobia and Euroscepticism have been observed (Boomgarden and Freiere 2009; Hobolt et al. 2011).

The ESS (2014) data also allow us to control for conventional explanatory factors of Eurosceptic attitudes beyond Islamophobia into the empirical analysis. We include mistrust in political institutions, the ideological left-right positioning of individuals, identity-based factors such

\footnotetext{
${ }^{5}$ We have coded the support of the following parties as a vote choice for right-wing populists: Freedom Party of Austria (FPÖ), Alliance for the Future of Austria (BZÖ), Flemish Interest (VB), National Front (FN), Freedom and Direct Party (SPD), Danish People's Party (DF), Conservative People's Party (EKRE), Finns Party (Ps), National Rally (FN), Alternative for Germany (AfD), Hungarian Civic Alliance (Fidesz), The Movement for a Better Hungary (Jobbik), Party for Freedom (PVV), Law and Justice (PiS), Sweden Democrats (SD), and the UK Independence Party (UKIP).
} 
as strong identification with one's own nation and threat perception towards immigrants. The structure of the data further allows us to incorporate utilitarian considerations. Some of these can be motivated either by egoistic considerations (i.e. well-educated and wealthy individuals are regarded as the winners of the process of Europeanisation) or by sociotropical considerations (e.g. an assessment of the economic situation of one's own nation) (Abts et al. 2009; McLaren 2007; Van Elsas et al. 2016). As a further robustness check, we control for the residence, gender and age of the respondents. For an overview of all indicators, please refer to the appendix.

We used multilevel analysis to test the hypotheses (Gelman and Hill 2007; Hox 2010). ${ }^{6}$ This statistical procedure fits the hierarchical structure of the data. In addition, we present other visualisations in order to make the findings accessible to a more intuitive interpretation.

\section{First Result: Anti-Muslim Attitudes Foster Euroscepticism, But...}

A superficial glance at Fig. 2 suggests that positions towards immigrants are subject to pragmatic and utilitarian considerations in most European societies. It is perceived as particularly important that immigrants adapt to their lifestyle, learn their language and possess the necessary work skills and educational qualifications needed in their countries. Conversely, however, this in no way means that ascriptive characteristics such as religious affiliation or even the skin colour of people are irrelevant. Many citizens in European societies openly admit that they would prefer immigrants with a Christian background and that they are opposed to the immigration of non-white people.

However, there are substantial differences between European societies. In Sweden, Germany and the Netherlands, only one in ten respondents considers a Christian background and the colour of people's skin to be an important criterion for the acceptability of immigrants.

In Lithuania, Poland, Hungary, the Czech Republic and Estonia, these ascriptive features of immigrants are considered important by one in four respondents. The preference of these particular selection criteria translates

\footnotetext{
${ }^{6} \mathrm{We}$ visualise the results of the multilevel analysis with the coefplot command (Jann 2014).
} 


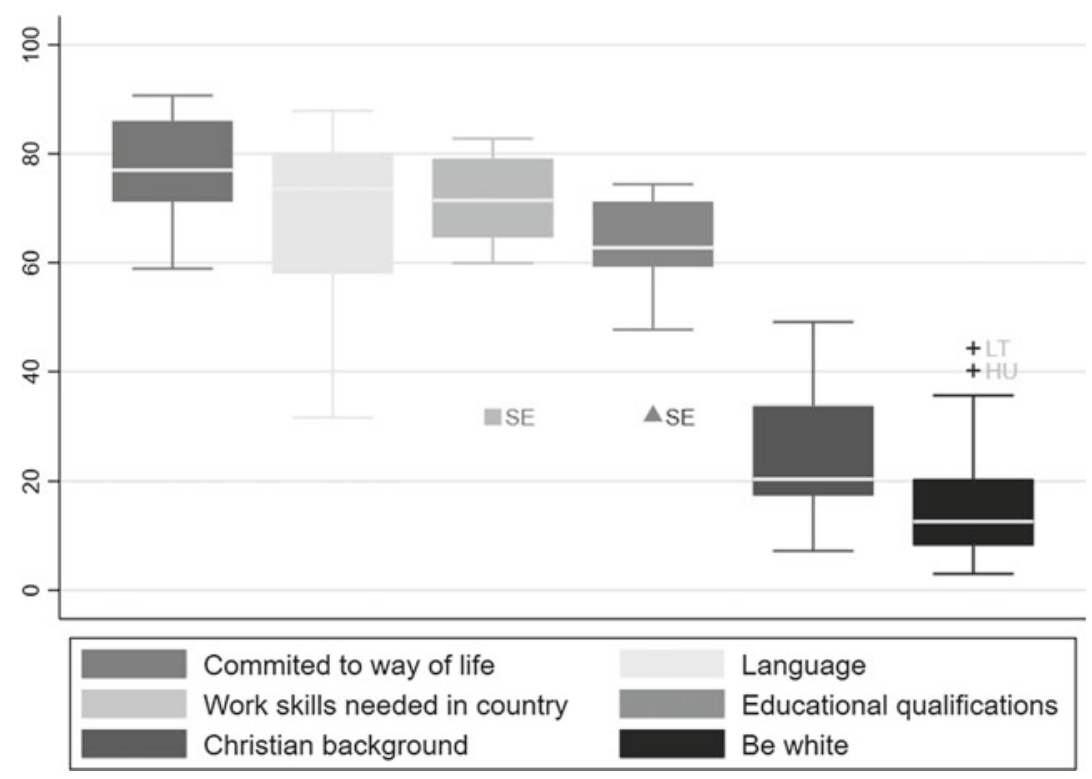

Fig. 2 Qualifications considered important for immigrants (Note The figure shows the percentage of agreement with these criteria. Source European Social Survey [2014])

into a predominantly pronounced rejection of Muslims, as Fig. 3 shows. Attitudes towards immigrants are subject to an explicit hierarchisation in all European societies. Immigrants from poorer EU member states are preferred over immigrants from poorer non-EU countries. The strongest rejection, however, is directed against Muslims. Again, notable differences between European societies catch the eye. While in Sweden, Germany and Denmark a Muslim ban is supported by less than $10 \%$ of the population, it is one in four in Poland, Lithuania and Estonia; even one in two in the Czech Republic and Hungary who would applaud it. To put it bluntly: The resistance of the Visegrád States' governments against binding quotas for the redistribution of refugees are in line with public opinion on this issue in their countries (Krastev 2018; Pickel and Öztürk 2018a).

But do these Islamophobic attitudes indeed foster negative attitudes towards the EU? The results obtained from the multilevel analysis in Fig. 4 validate the research-guiding hypothesis: individuals in favour 


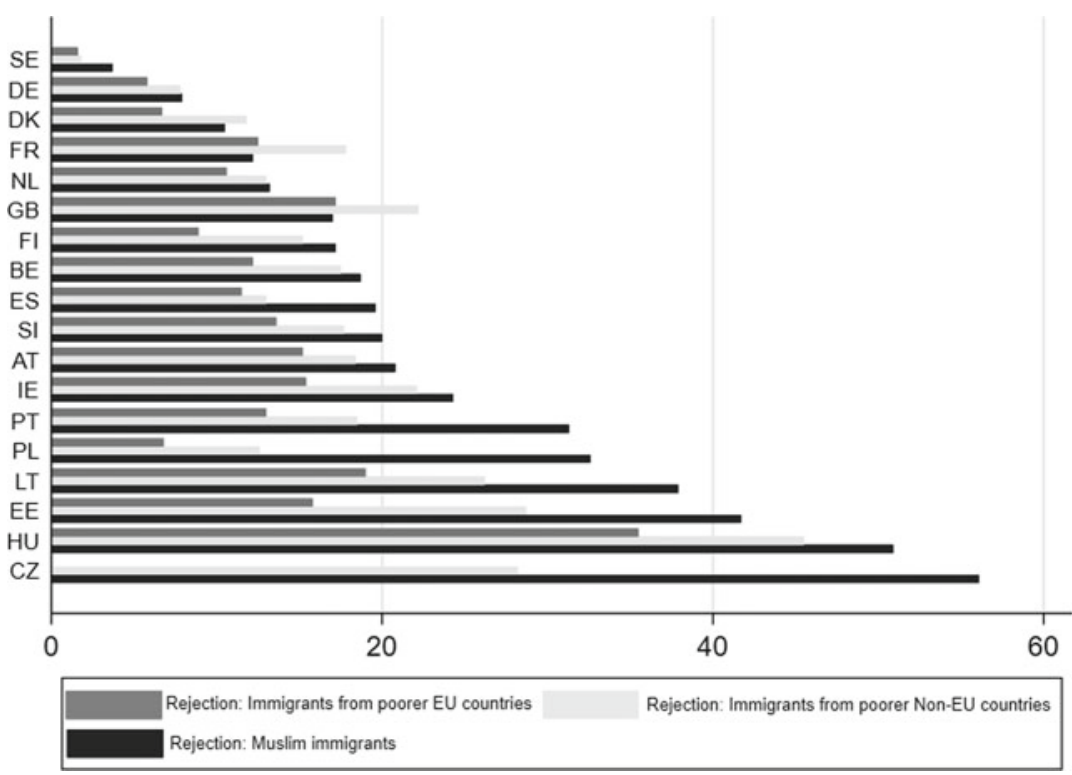

Fig. 3 Rejection of different groups of immigrants (Note The figure shows the rejection of these groups of immigrants in per cent. Source European Social Survey [2014])

of a Muslim ban are more likely to say that the European unification process has gone too far (bivariate regression coefficient $=0.219, p<$ $0.0001)$. To be sure, Islamophobic sentiments are not the only source of Euroscepticism. Beyond Islamophobia, negative attitudes towards the EU are facilitated by political and identity-based attitudes, utilitarian considerations and social structural characteristics of individuals.

Citizens who distrust national political institutions, who voted for right-wing populists in the last elections, who have a strong identification with their nation, who perceive migrants as a threat, and consider the current state of the economy to be precarious, tend to show negative attitudes towards the EU. The EU enjoys greater support among citizens with higher levels of education, inhabitants of large metropolitan areas and the younger generations. Yet, even under the control of these factors, there is a statistically robust linkage between Islamophobia and Eurosceptic attitudes (regression coefficient in the overall model $=0.086$, 


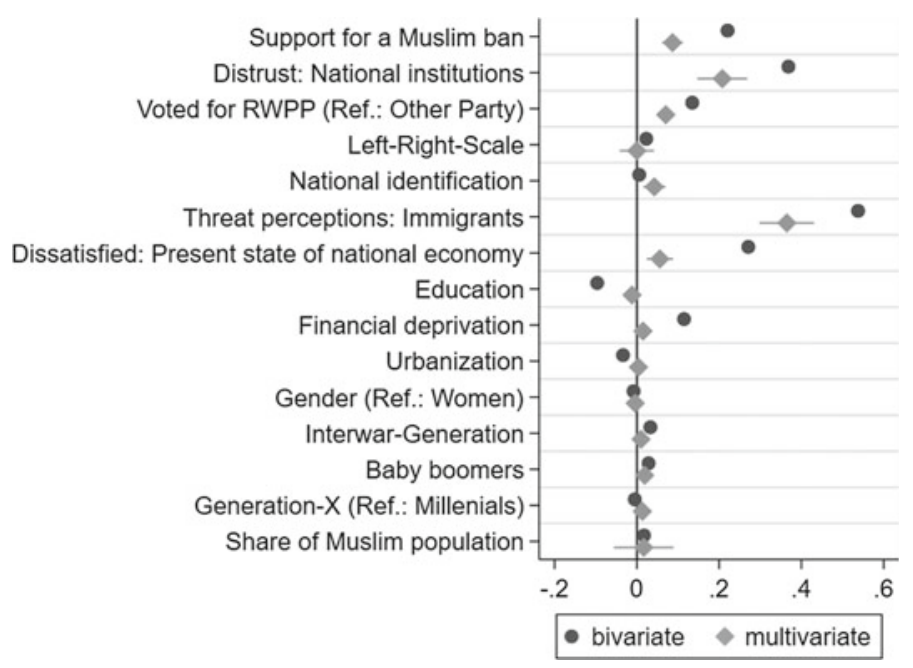

Fig. 4 Sources of Euroscepticism (Note The figure shows the results of a multilevel analysis. Individual-level variables are group-mean centred. The proportion of Muslims in the societies is grand-mean centred. The coefficients shown are based on robust standard errors. Number of countries: 18. Number of cases (total): 17,311. Number of cases (average): 962. Wald statistics: $874.53, p<$ 0.0001. Source European Social Survey [2014], PEW Research [2011], and Rooduijn et al. [2019])

$p<0.0001)$. In line with the Integrated Threat Theory, these results reveal that citizens who perceive immigrants and an ever-growing cultural diversity in their societies as a threat thus withdraw their support from the European project (Stockemer et al. 2019). The effect of socio-economic factors is practically negligible in comparison.

Are voters of right-wing populist parties the main bearers of the Islamophobia-Euroscepticism Nexus? In Fig. 5, we have plotted the average support of a Muslim ban in relation to the Eurosceptic attitudes of voters from all parties in the sample. ${ }^{7}$ Four ideal typical positions can be differentiated with the Scatterplot: (1) A non-Islamophobic support for Europe (bottom left), (2) a non-Islamophobic Euroscepticism (top left), (3) an

\footnotetext{
${ }^{7}$ To safeguard resilient empirical results, we only use parties with more than 20 respondents in the sample.
} 


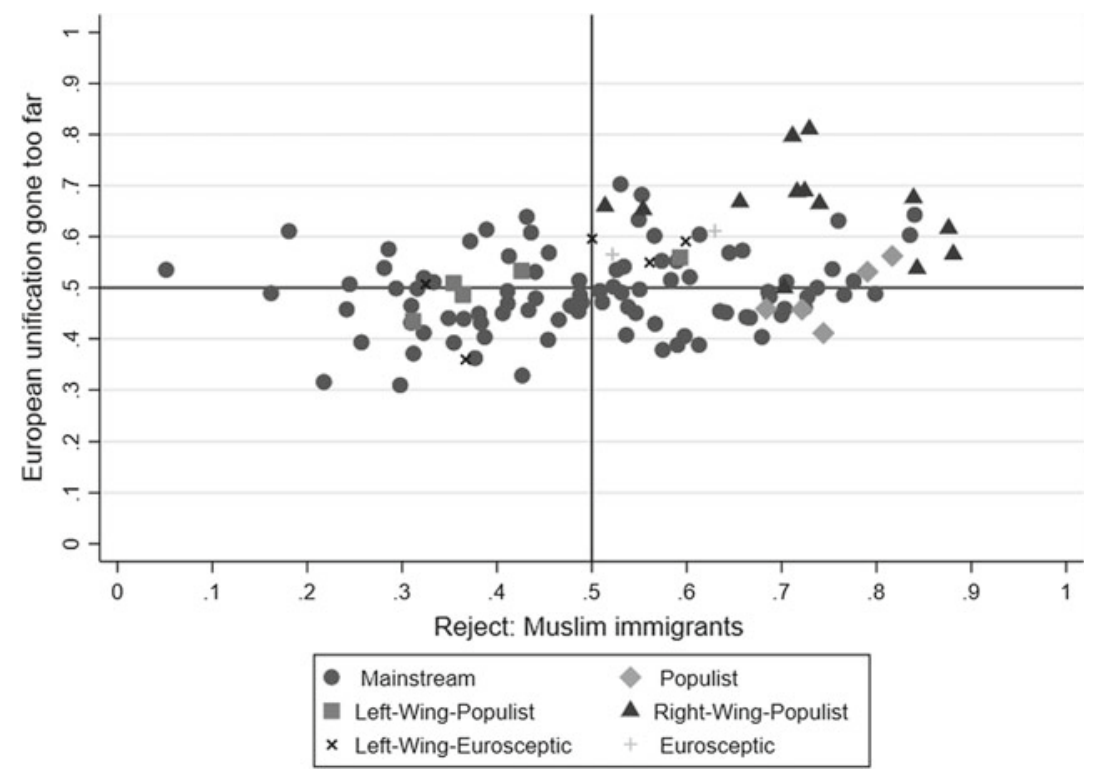

Fig. 5 Relationship between Islamophobic and Eurosceptic attitudes among voters of different parties (Note The Scatterplot relates the support for a Muslim ban to the perception that European unification has gone too far. This is the average attitude of voters from all parties of the sample examined with at least 20 respondents. Both scales were normalised to a range between 0 and 1 . In addition, we set two reference lines at their mean value. Source European Social Survey [2014] and Rooduijn et al. [2019])

Islamophobic support for Europe (bottom right) and (4) an Islamophobic Euroscepticism (top right). If we now locate the electorate of right-wing populist parties in this scatterplot, we can see that their average voters applaud a restrictive immigration policy against Muslims.

Except for the voters of the Polish PiS, a Eurosceptic attitude also prevails. To clarify: Voters of right-wing populist parties tend to be Islamophobic Eurosceptics. It is also clear, however, that they are not alone when it comes to these attitudes. Islamophobic Euroscepticism is a broader phenomenon, and it extends into the mainstream of European societies. Other groups featuring a combination of these attributes are, for example, voters of populist parties, to whom Rooduijn et al. (2019) do not attest a clear-cut nativist host ideology (e.g. the Czech ANO). 
The list also includes Eurosceptic parties (e.g. the Dutch 50PLUS), leftwing Eurosceptic parties (e.g. the Portuguese Coligação Democrática Unitária), left-wing populist parties (e.g. the Irish Sinn Féin), as well as the voters of liberal (e.g. the Danish Venstre), social-democratic (e.g. the Austrian SPÖ) and conservative (e.g. the British Tories) mainstream parties.

If we turn our focus to internal polarisation, then a blatant difference becomes apparent between Eastern European societies on the one hand, and Scandinavian and Western European societies on the other. Figure 6 shows that voters of right-wing populist parties in Scandinavia and Western Europe are much more Islamophobic and Eurosceptic than the average citizen - an ironic finding if we bear in mind that right-wing

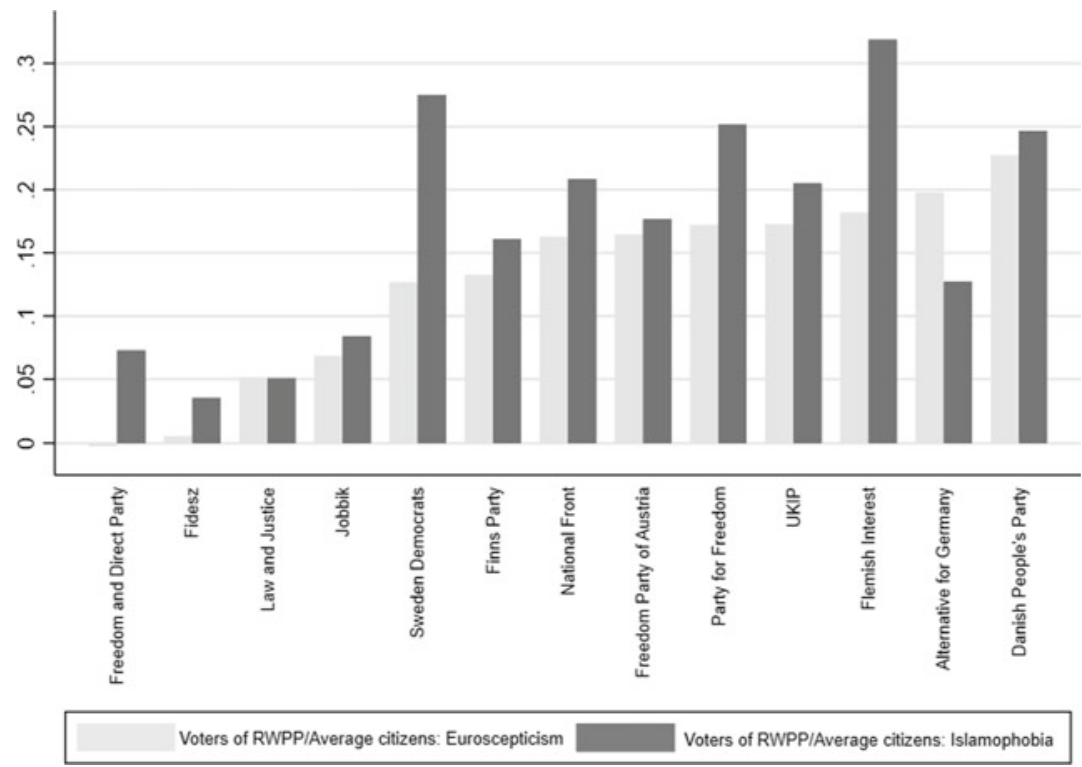

Fig. 6 Differences in Islamophobic and Eurosceptic attitudes between voters of right-wing populist parties and average citizens (Note The bar charts visualise the mean value differences between the attitudes of voters of right-wing populist parties and the average citizen in the respective societies. The Islamophobia and Euroscepticism scales were normalised to a range between 0 and 1 . Source European Social Survey [2014] and Rooduijn et al. [2019]) 
populists portray themselves as the voice of an alleged 'silent majority'. A very different picture emerges in post-socialist societies. The attitudes of voters of right-wing populist parties in Eastern Europe hardly differ from those of the average citizen. In fact, right-wing populists and mainstream politicians in Eastern Europe attempt to outbid each other when it comes to Islamophobic statements (Hafez 2018; Slačálek and Svobodová 2018). Tomio Okamura, chairperson of the right-wing populist Freedom and Direct Party, for example, has become famous across the borders of the Czech Republic for his call to take pigs and walk with them in front of mosques.

\section{Second Result: The Share of Muslims Does not Matter}

In East Central Europe, even among mainstream politicians, Islamophobic statements are no rarity. The Czech president and former chairman of the Czech Social Democrats Miloš Zeman considers Islam a 'religion of death' and declared in public that he considers the term 'moderate Muslim' to be an oxymoron, just as there would be no 'moderate Nazis' either (Trait 2016). Given that (right-wing) populist governments in the Czech Republic (ANO), Poland (PiS) and Hungary (Fidesz and Jobbik) have combined their nationalist course against immigrants with harsh criticism against the European Union's cosmopolitan elites, it is hardly surprising that the Islamophobia-Euroscepticism Nexus is not conditioned by the proportion of Muslims in the overall population (regression coefficient of cross-level interaction $=0.044, p>0.10$ ).

It may seem paradoxical that right-wing populists in Eastern Europe have become part of the anti-Islam chorus. From the perspective of the contact hypothesis (Allport 1971), however, this finding comes as little surprise. Anti-Muslim resentments are most widespread where Muslims rarely live (see Fig. 7). Since Muslims in Eastern Europe often do not even make up $1 \%$ of the population, personal experience cannot work to counter this attitude pattern. Thus, many Eastern Europeans do not have the opportunity to align the shrill statements of their governments with reality through real-life interactions with Muslims. What complicates matters is that so-called parasocial contacts (Horton and Wohl 1956) fill the place of a lack of personal contacts.

Several studies demonstrate that the media fill that void and shape the perception these voters have of Muslims. Further aggravating these views 


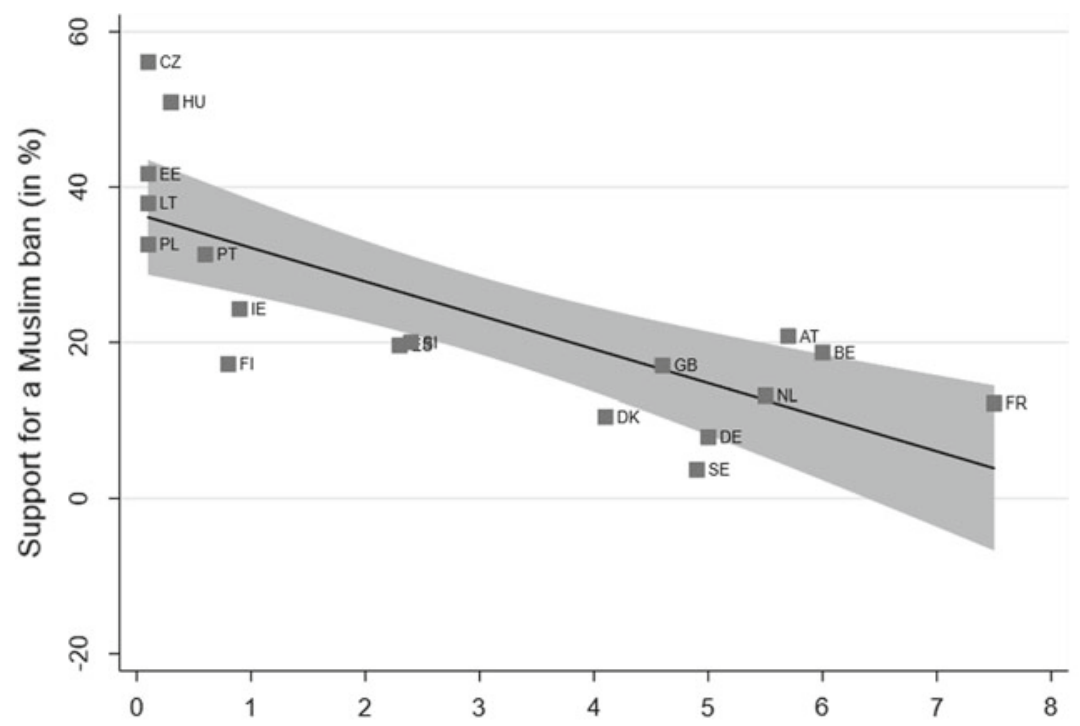

Share of Muslims as a percentage of total population in 2010 (PEW 2011)

Fig. 7 The relationship between the percentage of Muslims in the overall population and the support for a Muslim immigration ban (Note The scatterplot links the proportion of Muslims in the total population with the support for a Muslim ban. Source European Social Survey [2014], PEW Research [2011])

is a predominantly negative bias in reporting. News about conflict in the Middle East, a whole series of Islamist terrorist attacks in European cities committed by ISIS, and the image of no-go zones for whites in Muslimdominated neighbourhoods contribute to an image in which Muslimsas a collective-appear to be fanatical, violent and dangerous. The evergrowing dependency of the media on right-wing populist governments in Eastern Europe is likely to intensify this trend (Ahmed and Matthes 2016; Kalmar 2018; Pickel and Yendell 2016).

What this means is that for most Eastern Europeans living outside the large metropolitan areas there is hardly any possibility of countering these stereotypes with the reality that provides real contact with Muslims. The markedly varying share of Muslims in the total population, however, does not affect the Islamophobia-Euroscepticism Nexus, as shown in Fig. 8. 


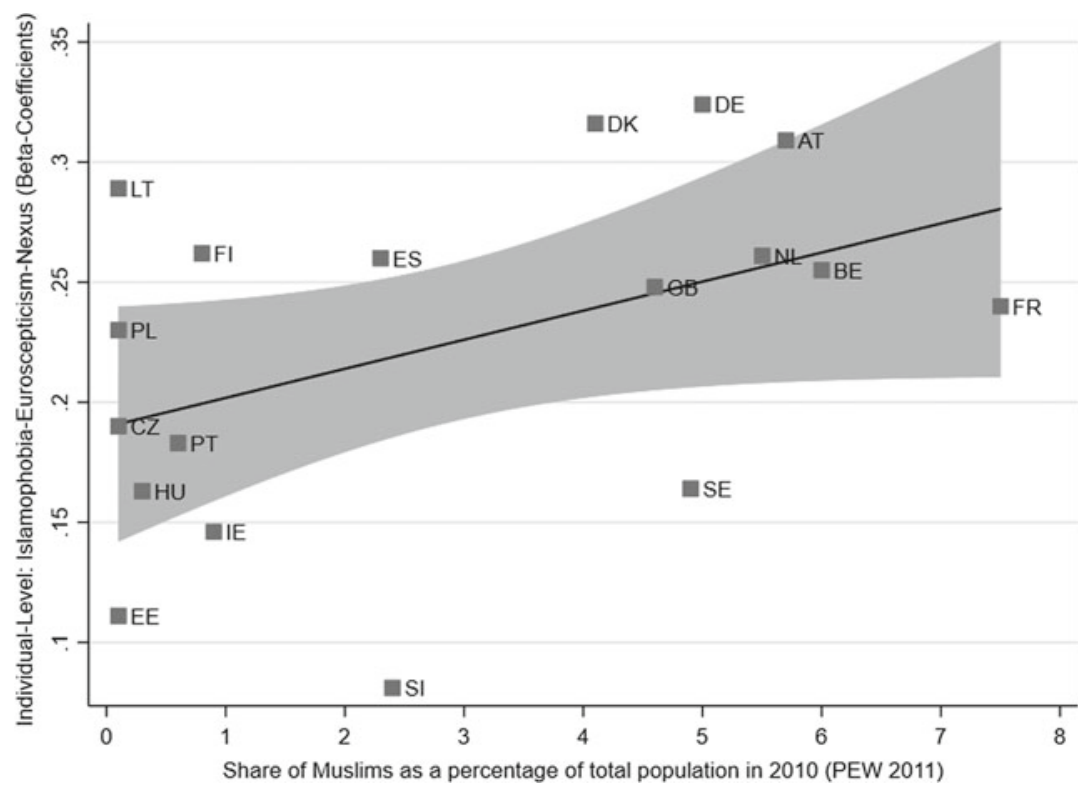

Fig. 8 The moderating effect of the share of Muslims as a proportion of the total population on the Islamophobia-Euroscepticism Nexus

(Note The scatterplot relates the individual-level effect of Islamophobic attitudes on Eurosceptic opinions to the percentage of Muslims in the total population. The beta coefficients were extracted from regression analyses. They provide information about the strength of the Islamophobia-Euroscepticism Nexus at the individual level in the 18 investigated societies. We controlled for left-right orientation, education, place of residence, gender and age of the respondents. Source European Social Survey [2014] and PEW Research [2011])

This result underlines the importance of subjective perceptions of citizens. When individuals perceive Muslims as a threat and embrace a restrictive immigration policy towards Muslim immigrants, they tend to display more Eurosceptic attitudes in all societies under study. The strength of the Islamophobia-Euroscepticism Nexus effect is more pronounced in the Czech Republic and Poland than in Sweden, as well as more pronounced in Lithuania than in France. In short: The presence or absence of Muslims is of secondary importance when it comes to the strength of the individual-level linkage between Islamophobia and Euroscepticism. 


\section{Conclusion: Right-Wing Populists, Euroscepticism and How the EU Can Deal with It}

To summarise, our results indicate a robust relationship between the support for a Muslim ban and the perception that the European unification process has gone too far. The setting provided by the so-called refugee crisis served to reveal Islamophobia as a major stress factor for the EU. It even fosters a perception of distance between citizens and European institutions.

Voters of right-wing populist parties are the main bearers of this Islamophobic Euroscepticism. Crossed-out mosques, the collective demonisation of Muslims as rapists, and the call to defend the so-called Christian Occident have become their pan-European core brand. Rightwing populists combine Islamophobia with fierce criticism of the allegedly corrupted national and European elites. According to their rhetoric, bureaucrats in distant Brussels allegedly orchestrated the so-called invasion of the Muslims to promote what they refer to as the 'great exchange'. This might sound shrill. Yet, our findings reveal that right-wing populists target their attacks on an already unpopular group of people. There are deep-rooted cultural and historical resentments against Muslims. Additionally, and since the rise of Islamist terrorism, Muslims appear to many EU citizens as fanatical, dangerous and, above all, violent. With the so-called refugee crisis, latent resentments against Muslims gained new intensity or were activated anew. Europe's right-wing populists serendipitously welcomed these events and have been profiting from them (see Norris and Inglehart 2019).

A new tendency is that Eastern European right-wing populists have become a vocal part of the anti-Islam chorus, although (or specifically because) Muslims constitute a marginal group there. Their hostilities used to be directed against the Roma and other minority groups present in their societies. In line with the contact hypothesis, it is precisely the absence of Muslims that favours an anti-Muslim social climate. Therefore, 'Islamophobia without Muslims' provides a dividend for Eastern European right-wing populists. Wherever they control the government, they use their great influence on the media to construct a fear-mongering image of Islam and Muslims.

Politicians such as Viktor Orbán in Hungary and Lech Kaczyński in Poland hope that this rhetoric can yield advantages in national elections-even more since voters from right-wing populist and mainstream 
parties largely agree in their rejection of Muslim immigrants. Moreover, the stereotypes of Muslims transmitted by the media cannot be adapted to a more profane reality through contacts. Since the EU is pushing for mandatory quotas for the distribution of refugees, populist attacks against the elites can be further projected towards Brussels. For populists in decision-making positions, this rhetoric is very attractive.

Spurred by the right-wing populists' rhetoric, many citizens are now under the impression that the EU wants to impose on them unwanted refugees from the Middle East. The shrillest voices even claim that the foreign rule of the Kremlin was replaced by Brussels (Kalmar 2018; Krastev 2018). But as we have shown, the anti-immigration stance of the Visegrád States reflects a congruence between government behaviour and public opinion. For many Eastern Europeans, a restrictive immigration policy is a top priority. The so-called refugee crisis served to reveal diverging attitudes between Western and Eastern Europe and fuelled their conflict potential. These rifts further endanger the EU's legitimacy (which was never particularly pronounced anyway), undermine even weak versions of the European project and have led to serious controversies between the EU's 28 member states.

It almost seems as if Visegrád's protectionist position has triggered an imitation effect among the right-wing populists of Western Europe. They present their agenda with more self-confidence than ever before, and force supporters of a cosmopolitan Europe into defensive positions. By doing well in elections, right-wing populist parties have moved from the margins into the mainstream of most party systems. For fear of further losses of their votes, mainstream politicians like Horst Seehofer and Sebastian Kurz team up with Viktor Orbán. Their goal is to further strengthen and safeguard the walls of 'Fortress Europe'. Inside the EU, attacks on Muslims and their places of worship have increased in recent years. A mutual recognition of all citizens as free and equal (Habermas 1996) is thus in danger. Their current target is Muslims, but these attacks are clearly against the open society and the European project.

The consequences for the EU are controversial. It is hard to deny that the so-called refugee crisis has led to a loss of reputation for the EU. Egoistic national tendencies do not only complicate supranational solutions to immigration policy issues. The anti-immigration campaign of the Visegrád States has facilitated the power ascension and consolidation of (right-wing) populist governments. The signs of the times point to an unprecedented comeback of nationalism. In these circumstances, 
a deepening of the European project is hardly realistic. However, even right-wing populists are quite divided on the consequences to be drawn from their EU criticism. The options range from promoting an exit to the attempt to rebuild the European project in an anti-cosmopolitan manner. Kalmar (2018) argues that right-wing populist politicians and their parties in Eastern Europe are not necessarily against the EU. Their dependence on its structural and investment funds is too great for this. Rather, their political mission is to create a 'different EU', that is, a 'Fortress Europe' that protects them from rejected (Muslim) immigrants. In fact, the Euroscepticism that exists in Eastern Europe therefore does not question EU membership. This alliance with other European countries is seen in the Baltic States and Poland as a guarantee of independence from Russia. Their Euroscepticism is aimed rather at different EU policies.

\section{REFERENCES}

Abts, K., D. Heerweght, and M. Swyngedouw. 2009. Sources of Euroscepticism: Utilitarian Interest, Social Distrust, National Identity and Institutional Distrust. World Political Science 5 (1): 2363-4774.

Ahmed, S., and J. Matthes. 2016. Media Representation of Muslims and Islam from 2000 to 2015: A Meta-Analysis. International Communication Gazette 79 (3): 219-244.

Allport, Gordon W. 1971. Die Natur des Vorurteils. Köln: Kiepenheuer \& Witsch.

Azrout, R., J.H.P. van Spanje, and C.H. de Vreese. 2013. Focusing on Differences? Contextual Conditions and Anti-Immigrant Attitudes' Effects on Support for Turkey's EU Membership. International Journal of Public Opinion Research 5 (4): 480-501.

Boomgaarden, H.G., and A. Freire. 2009. Religion and Euroscepticism. West European Politics 32 (6): 1240-1265.

Castanho Silva, Bruno. 2018. The (Non)Impact of the 2015 Paris Terrorist Attacks on Political Attitudes. Personality and Social Psychology Bulletin 44 (6): 838-850.

Ciftci, Sabri. 2012. Islamophobia and Threat Perceptions: Explaining AntiMuslim Sentiments in the West. Journal of Muslim Minority Affairs 32 (3): 293-309.

Eurobarometer. 2018. Standard Eurobarometer 89: Spring 2018. https://ec. europa.eu/commfrontoffice/publicopinion/index.cfm/Survey/getSurveyDet ail/instruments/STANDARD/surveyKy/2180. Accessed 2 March 2020.

European Social Survey Round 7 Data. 2014. Data File Edition 2.2. NSD: Norwegian Centre for Research Data, Norway-Data Archive and Distributor 
of ESS Data for ESS ERIC. https://www.europeansocialsurvey.org/. Accessed 2 March 2020.

Gelman, A., and J. Hill. 2007. Data Analysis using Regression and Multilevel/Hierarchical Models. Cambridge: Cambridge University Press.

Gorodzeisky, A, and M. Semyonov. 2019. Perceptions and Misperceptions: Actual Size, Perceived Size and Opposition to Immigration in European Societies. Journal of Ethnic and Migration Studies 37: 1-19.

Habermas, Jürgen. 1996. Die Einbeziehung des Anderen. Studien zur politischen Theorie. Frankfurt am Main: Suhrkamp.

Hafez, Farid. 2014. Shifting Borders: Islamophobia as Common Ground for Building Pan-European Right-Wing Unity. Patterns of Prejudice 48 (5): 479499.

Hafez, Farid. 2018. Street-Level and Government-Level Islamophobia in the Visegrád Four Countries. Patterns of Prejudice 52 (5): 436-447.

Hobolt, S.B., W. van der Brug, C.H. de Vreese, H.G. Boomgaarden, and M.C. Hinrichsen. 2011. Religious Intolerance and Euroscepticism. European Union Politics 12 (3): 359-379.

Hortin, D., and R. Wohl. 1956. Mass Comunication and Para-Social Interaction: Observations on Intimacy at a Distance. Psychiatry 19 (2): 215-229.

Hox, Joop. 2010. Multilevel Analysis: Techniques and Applications. London: Routledge.

Jann, Ben. 2014. Plotting Regression Coefficients and other Estimates. The Stata Journal 14: 708-737.

Kallis, Aristotle. 2018. The Radical Right and Islamophobia. In The Oxford Handbook of the Radical Right, ed. J. Rydgren, 42-60. Oxford: Oxford University Press.

Kalmar, Ivan. 2018. The Battlefield Is in Brussels': Islamophobia in the Visegrád Four in its Global Context. Patterns of Prejudice 52 (5): 406-419.

Krastev, Ivan. 2018. Europadämmerung. Frankfurt am Main: Suhrkamp.

Marfouk, Abdeslam. 2019. I'm Neither Racist nor Xenophobic, But: Dissecting European Attitudes Towards a Ban on Muslims' Immigration. Ethnic and Racial Studies 42 (10): 1747-1765.

McLaren, Lauren. 2007. Explaining Mass-Level Euroscepticism: Identity, Interests, and Institutional Distrust. Acta Politica 42 (2-3): 233-251.

Mudde, Cas. 2019. The Far Right Today. Cambridge: Polity Press.

Mudde, Cas, and C.R. Kaltwasser. 2017. Populism: A Very Short Introduction. Oxford: Oxford University Press.

Norris, P., and R. Inglehart. 2019. Cultural Backlash: Trump, Brexit, and Authoritarian Populism. Cambridge: Cambridge University Press.

PEW Research Center. Religion \& Public Life. 2011. Muslim Population by Country. https://www.pewforum.org/2011/01/27/table-muslim-popula tion-by-country/. Accessed 2 March 2020. 
Pickel, Gert. 2018. Perceptions of Plurality: The Impact of the Refugee Crisis on the Interpretation of Religious Pluralization in Europe. In Religion in the European Refugee Crisis. Religion and Global Migrations, ed. U. Schmiedel and G. Smith, 15-38. Cham: Palgrave Macmillan.

Pickel, G., and C. Öztürk. 2018a. Nationalism and Perceptions of Threat-Ethnocentrism or Just a Lack of Contact? Islamophobia in Eastern Europe from a Comparative Perspective. https://www.leibniz-eega.de/wp-content/uploads/ 2019/03/EEGA_Special-Issue_1_Islamophobia.pdf. Accessed 2 March 2020.

Pickel, G., and C. Öztürk. 2018b. Islamophobia Without Muslims? The 'Contact Hypothesis' as an Explanation for Anti-Muslim Attitudes-Eastern European Societies in a Comparative Perspective. Journal of Nationalism, Memory o Language Politics 12 (2): 162-191.

Pickel, G., and S. Pickel. 2019. Der 'Flüchtling' als Muslim - und unerwünschter Mitbürger? In Flucht und Migration in Europa. In Neue Herausforderungen für Parteien, Kirchen und Religionsgemeinschaften, ed. O. Hidalgo and G. Pickel, 279-323. Wiesbaden: Springer VS.

Pickel, G., and A. Yendell. 2016. Islam als Bedrohung? Beschreibung und Erklärung von Einstellungen zum Islam im Ländervergleich. Zeitschrift Für Vergleichende Politikwissenschaft 3-4: 273-309.

Pickel, G., and A. Yendell. 2018. Religion als konfliktärer Faktor im Zusammenhang mit Rechtsextremismus, Muslimfeindschaft und AfD-Wahl. In Flucht ins Autoritüre. Rechtsextreme Dynamiken in der Mitte der Gesellschaft, ed. O. Decker and E. Brähler, 217-242. Gießen: Psychosozial-Verlag.

Pickel, Susanne. 2016. Methodologische Grundlagen des Vergleichs und Vergleichsdesigns. In Handbuch Vergleichende Politikwissenschaft, ed. H.-J. Lauth, M. Kneuer, and G. Pickel, 25-45. Wiesbaden: VS Verlag.

Rooduijn, M., S. van Kessel, C. Froio, A. Pirro, S. de Lange, D. Halikiopoulou, P. Lewis, C. Mudde, and P. Taggart. 2019. The PopuList: An Overview of Populist, Far Right, Far Left and Eurosceptic Parties in Europe. https://populist.org/. Accessed 2 March 2020.

Roodujin, M., and S. van Kessel. 2019. Populism and Euroscepticism in the European Union. https://oxfordre.com/politics/view/10.1093/acrefore/ 9780190228637.001.0001/acrefore-9780190228637-e-1045. Accessed 2 March 2020.

Schlueter, E., A. Masso, and E. Davidov. 2019. What Factors Explain AntiMuslim Prejudice? An Assessment of the Effects of Muslim Population Size, Institutional Characteristics and Immigration-related Media Claims. Journal of Ethnic and Migration Studies 46: 1-16.

Stark, T., S. Pickel, and G. Pickel. 2020. Determinanten der Wahlentscheidung zwischen expandierendem nationalistischem Rechtspopulismus und Erwartungen an die integrative Kraft der EU. In Europawahl 2019, ed. M. Keading. Wiesbaden: Springer (in Press). 
Slačálek, O., and E. Svobodová. 2018. The Czech Islamophobic Movement: Beyond 'Populism'? Patterns of Prejudice 52 (5): 479-495.

Steenbergen, M.R., E.E. Edwards, and C.E. De Vries. 2007. Who's Cueing Whom? Mass-Elite Linkages and the Future of European Integration. European Union Politics 8 (1): 13-35.

Stephan, W.G., and C.W. Stephan. 1996. Predicting Prejudice. International Journal of Intercultural Relations 20 (3-4): 409-426.

Stockemer, D., A. Niemann, J. Rabenschlag, J. Speyer, and D. Unger. 2018. Immigration, Anti-Immigrant Attitudes and Euroscepticism: A Meta-Analysis. French Politics 16 (3): 328-340.

Stockemer, D., A. Niemann, D. Unger, and J. Speyer. 2019. The "Refugee Crisis", Immigration Attitudes and Euroscepticism. International Migration Review 53: 1-30.

Tajfel, Henri. 1982. Social Identity and Intergroup Relations. Cambridge: Cambridge University Press.

Trait, Robert. 2016. Miloš Zeman: The Hardline Czech Leader Fanning Hostility to Refugees. The Guardian. https://www.theguardian.com/world/ 2016/sep/14/milos-zeman-czech-leader-refugees. Accessed 2 March 2020.

Van Elsas, E.J., A. Hakhverdian, and W. van der Bourg. 2016. United Against a Common Foe? The Nature and Origins of Euroscepticism among Left-Wing and Wight-Wing Citizens. West European Politics 39 (6): 1181-1204.

Werts, H., P. Scheepers, and M. Lubbers. 2013. Euroscepticism and Radical Right-Wing Voting in Europe, 2002-2008: Social Cleavages, Socio-Political Attitudes and Contextual Characteristics Determining Voting for the Radical Right. European Union Politics 14 (2): 183-205.

Yavçan, Başak. 2013. Public Opinion Toward Immigration and the EU. Turkish Studies 14 (1): 158-178. 
Open Access This chapter is licensed under the terms of the Creative Commons Attribution 4.0 International License (http://creativecommons.org/licenses/ by $/ 4.0 /$ ), which permits use, sharing, adaptation, distribution and reproduction in any medium or format, as long as you give appropriate credit to the original author(s) and the source, provide a link to the Creative Commons license and indicate if changes were made.

The images or other third party material in this chapter are included in the chapter's Creative Commons license, unless indicated otherwise in a credit line to the material. If material is not included in the chapter's Creative Commons license and your intended use is not permitted by statutory regulation or exceeds the permitted use, you will need to obtain permission directly from the copyright holder.

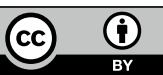

